\title{
Species diversity and molecular analysis of opportunistic Mycobacterium, Nocardia and Rhodococcus isolated from the hospital environment in a developing country, a potential resources for nosocomial infection
}

Marzieh Siavashifar ${ }^{1}$, Fatemeh Rezaei ${ }^{1}$, Tahereh Motallebirad², Davood Azadi ${ }^{*}$ (D, Abdorrahim Absalan², Zahra Naserramezani ${ }^{1}$, Mohadeseh Golshani ${ }^{1}$, Morteza Jafarinia ${ }^{3}$ and Kazem Ghaffari ${ }^{2}$

\begin{abstract}
Background: Hospital environmental resources have a significant role in cross-transmission of opportunistic pathogens such as actinomycetes species to the patients. Actinomycetes have a remarkable capability to survive in adverse and harsh conditions of hospital environments; therefore, they are a threat to the health of patients. Due to this issue, we aimed to determine the frequency and diversity of actinomycetes species in hospital soil, water and dust by using a combination of conventional and molecular methods including the phenotypic and biochemical tests for preliminary identification and the PCR amplification of the specific region of the 16S rRNA, hsp65 gene and sequence analyses of $16 \mathrm{~S}$ rRNA for the genus and species identification.

Results: A total of 50 (35.2\%) actinomycetes isolates from 7 genera were isolated from 142 hospital environmental samples. The three most prevalent species were M. setense 10\%, R. erythropolis and M. fortuitum $8 \%$ followed by N.cyriacigeorgica and M. gordonae 6\%, M. chelonae, M. abscessus, M. lentiflavum, M. mucogenicum, N. asteroides, N. farcinica, R. equi and L. shinushuensis $4 \%$ and the single isolates of $M$. conceptionense, M. septicum, N. rhamnosophilia, $N$. bravicatena, M. flavescens, M. arupense, M. doricum, M. frederiksbergense, S. heliomycini, S. albus, S. albogriseolus, $R$. facians, D. maris, G. terae and A. globiformis.
\end{abstract}

Conclusions: In conclusion we showed that the hospital environment is a potential reservoir for a broad range of actinomycetes species, due to the remarkable survival capability of these microorganisms in adverse hospital environment, carrying a threat to the health of patients.

Keywords: $16 \mathrm{~S}$ rRNA, Actinomycetes, Hospital environment, Nosocomial infection

*Correspondence: Davood.azadi@gmail.com

${ }^{2}$ Department of Basic and Laboratory and Sciences, Khomein University of Medical Sciences, Qods street, Khomein, Iran

Full list of author information is available at the end of the article

C C The Author(s). 2021 Open Access This article is licensed under a Creative Commons Attribution 4.0 International License, which permits use, sharing, adaptation, distribution and reproduction in any medium or format, as long as you give appropriate credit to the original author(s) and the source, provide a link to the Creative Commons licence, and indicate if changes were made. The images or other third party material in this article are included in the article's Creative Commons licence, unless indicated otherwise in a credit line to the material. If material is not included in the article's Creative Commons licence and your intended use is not permitted by statutory regulation or exceeds the permitted use, you will need to obtain permission directly from the copyright holder. To view a copy of this licence, visit http://creativecommons.org/licenses/by/4.0/ The Creative Commons Public Domain Dedication waiver (http://creativecommons.org/publicdomain/zero/1.0/) applies to the data made available in this article, unless otherwise stated in a credit line to the data. 


\section{Introduction}

Actinomycetes is a general term for the heterogeneous group of gram-positive bacteria with fungal morphology growing as anaerobic facultative or aerobic rods [1]. They are widely distributed in nature, particularly in soil and water and they make a considerable portion of the soil microflora $\left(10^{+4} 10^{+6} \mathrm{CFU} / \mathrm{mL}\right)\left(10^{+7} \mathrm{~W} 22 ; 10^{+8}\right.$ $\mathrm{CFU} / \mathrm{mL}$ ) and also found as members of the normal microbiota in open cavities, upper respiratory tract, especially the oropharynx, female genital tract, and gastrointestinal tract $[2,3]$.

Bacteria in the actinomycetes group consist of more than eight genera and 500 officially recognized species [4]. The major genera in the actinomycetes group are Actinomyces, Corynebacterium, Mycobacterium, nocardioform bacteria, and Streptomyces. Among the different identified actinomycetes species, only a few of them such as Nocardia, Mycobacterium, and Actinomyces cause infection in human and animal. However, nowadays several other species are being increasingly recognized as significant pathogens in immunocompromised patients such as patients with AIDS, transplanted neoplastic diseases, diabetic patients, patients under immunosuppressive therapy, and those with autoimmune disorders and cancerous patients [5-7]. However, several recent reports indicated that bacteria belonged to actinomyces group can produce infections in immune-competent population with no preexisting illness, trauma, or immunosuppressive therapy $[8,9]$. Some of these infection due to actinomycetes group are as follows: $N$. cyriacigeorgica, $N$. beijingensis and $N$. asteroides caused brain and organ abscess, $M$. avium and $M$. smegmatis caused pulmonary infection, $A$. meyeri and $R$. equi caused disseminated infection [10-13].

The ubiquitous nature of actinomycetes allows their persistence in environmental biofilms. This capability within hospitals environments such as medical devices and water pipes or other healthcare units represents a threat to human health are present in hospital. This issue caused colonization, pseudo-infection or infection during hospitalization or after discharge by moreindolent organisms, such as actinomycetes species [14, 15]. Due to increased incidence of diseases and nosocomial infections in immune-competent population with actinomycetes group underlined the important effects of actinomycetes genera on human health [15-17].

There is no evidence for person-to-person transmission of actinomycetes, nevertheless the high-resistance nature of actinomycetes species allows their persistence in adverse and harsh conditions such as hospital environment [18]. This survival capability within hospital environments such as water resources, soil and dust and medical devices represents a threat to health of susceptible hosts including patients and hospital staff. They respond to variations such as heat or cold shocks, oxygen deprivation, $\mathrm{pH}$ changes, exposure to toxins and antibiotics in the environment by exhibiting altered growth and characteristics that favor the onset and spread of hospital-acquired infection (HAI) [19].

Although many of the opportunistic infections associated with actinomycetes have been reported to be common in developed countries such as Iran [20]. However, there has been a few extensive reports on the diversity and potential inhabitants of actinomycetes in hospital environments from developing countries [14, 21].

The identification of actinomycetes species in the developing countries has been done using conventional microbiological methods such as acid-fast staining, semiquantitative, and heat-stable $\left(68^{\circ} \mathrm{C}\right)$ catalase production and niacin accumulation, pyrazinamide and growth on MacConkey agar without crystal violet [22], though isolation and accurate identification of isolates are difficult. Molecular tests that are currently applied provide a conclusive approach for the identification of Nontuberculous Mycobacteria (NTM). The molecular test strategies most often used are PCR-based RFLP (PRA) and sequence analysis of variable regions within microbial conserved genes, including rpoB or hsp65 and $16 \mathrm{~S}$ rRNA [23, 24].

The aim of this study was to appraise the frequency and diversity of actinomycetes species which have the survival capability in the hospital environments, by applying molecular and phenotypic microbiologic methods in order to provide a better insight into their likely role as a reservoir for the transmission and development of nosocomial infections.

\section{Materials and methods \\ Sampling}

For isolation of environmental actinomycetes from July 2018 to November 2019, a total number of 142 environmental samples including dust, soil and drinking and non-drinking water (tap water, shower and well water) were collected aseptically in sterile bottles from different departments and environments of 13 hospitals in the Markazi province of Iran. Temperature and $\mathrm{pH}$ for each sample were measured by standard methods. The samples were processed based on standard protocols.

In summary, for aquatic samples, each liter was transported at $4{ }^{\circ} \mathrm{C}$ to the laboratory and processed within a maximum period of $24 \mathrm{~h}$. Since the final goal was to screen and isolate mycobacterial species, initially the collected water samples were treated with $0.005 \%$ cetylpyridinium chloride (CPC) for $15 \mathrm{~min}$ to reduce the number of not-desirable microbial contaminants such as fungi, protista and other bacteria. Afterwards, the pretreated samples were subjected to vacuum filtration (cellulose nitrate $0.45 \mu \mathrm{m}$, Sartorius AG, Gottingen, Germany). 
The filters were rinsed and soaked in tubes containing $15 \mathrm{~mL}$ of distilled water. Almost $100 \mathrm{~mL}$ aliquots of dissolved filters were transferred into tubes of Lowenstein-Jensen (LJ) media and sauton's media supplemented with antifungal and antibacterial antibiotics [kanamycin, nystatin and nalidixic acid (each at $\left.50 \mu \mathrm{g} \mathrm{mL} \mathrm{m}^{-1}\right)$ ], and was incubated at a temperature between $25^{\circ} \mathrm{C}, 35^{\circ} \mathrm{C}$ and $42{ }^{\circ} \mathrm{C}$ in an atmosphere of $5 \%$ $\mathrm{CO} 2$ for 8 weeks [25].

For soil samples, $3-5 \mathrm{~g}$ soil were taken from potentially microbial contamination site in the hospital environment include: hospital green space, pots inside the patient's room, door and window labels, patient beds, hospital equipment, and nursing station. Then transferred directly to the laboratory. Three grams of soil were transferred to $50 \mathrm{~mL}$ sterile centrifuge tube. Then, $20 \mathrm{~mL}$ sterile distilled water was added to the tube and shacked for $5 \mathrm{~min}$, and centrifuged at $4300 \mathrm{RCF}$ at room temperature for $20 \mathrm{~min}$. The pellet and supernatant were decontaminated in separate tubes using 3\% sodium lauryl sulfate and $1 \% \mathrm{NaOH}$ (Kamala et al., 1994a). Afterwards, $100 \mu \mathrm{L}$ of the decontaminated sample was used to inoculate LJ media and sauton's media and was incubated at $25^{\circ} \mathrm{C}, 35^{\circ} \mathrm{C}$ and $42^{\circ} \mathrm{C}$ with $5 \% \mathrm{CO}_{2}$ atmosphere for 8 weeks [26].

For the dust samples, 2-3g dust were collected from the floors and window panes of patients' rooms with a sterile swab or brush, suspended in $100 \mathrm{~mL}$ distilled water for $60 \mathrm{~min}$, and allowed to stand at room temperature for additional $10 \mathrm{~min}$. Tenfold dilutions of the homogenized suspensions were prepared and $100 \mu \mathrm{l}$ of each of the pretreated $10^{-2}, 10^{-3}$, and $10^{-4}$ dilutions were inoculated into $\mathrm{LJ}$ media and Sauton's media and incubated for 8 weeks at $25^{\circ} \mathrm{C}$, $35^{\circ} \mathrm{C}$ and $42{ }^{\circ} \mathrm{C}$ with $5 \% \mathrm{CO}_{2}$ atmosphere [27]. The details of environmental samples tested during this study are given in Table 1.

This study was approved by the ethics committee Khomein University of Medical Sciences (Grant No. 3021).

\section{Conventional identification of isolates}

The environmental isolates were characterized phenotypically as actinomycetes group (nocardia, rhodococcus, mycobacterium, streptomyces, actinomyces, gordonae and arthrobacter) applying conventional phenotypic and biochemical tests. The tests included acid-fast and partial acid- fast staining, tween opacity, semi-quantitative, and heat-stable $\left(68^{\circ} \mathrm{C}\right)$ catalase production, growth at $25,32,37$, and $42^{\circ} \mathrm{C}$, urease activity, niacin accumulation, nitrate reduction, resistance to lysozyme, hydrolysis of tyrosine, xanthine, hypoxanthine tests tellurite reduction, and pigment production $[18,28]$.

\section{Molecular identification DNA extraction and purification}

Chromosomal DNA was extracted using simple boiling method or pitcher method with some modifications, [29, 30]. In modified pitcher method, lysis of actinomycetes cells carried out using sonication pretreatment followed by cell wall disruption with lysozyme $(200 \mathrm{mg} / \mathrm{mL}$ final concentration) and proteinase $\mathrm{K}(300 \mu \mathrm{g} / \mathrm{mL}$ final concentration) in the presence of sodium dodecyl sulfate (SDS) and finally treatment with guanidine-sarcosyl solution. After extraction of the DNA-containing aqueous phase with phenol-chloroform-isoamyl alcohol (25:24:1, $\mathrm{vol} / \mathrm{vol} / \mathrm{vol})$ and chloroform-isoamyl alcohol (24:1, vol/ vol), DNA was precipitated with ethanol at $-20^{\circ} \mathrm{C}$. Precipitated DNA was washed with $70 \%$ ethanol and resuspended in $100 \mu \mathrm{l}$ of Milli-Q water (23). Simple boiling method was performed as follow: a few colonies of bacteria were added into $200 \mathrm{~mL}$ of TE buffer (Tris EDTA), boiled for $30 \mathrm{~min}$ and centrifuged at $10000 \mathrm{rpm}$ for 10 min. The supernatant was transferred to another sterile microtube and centrifuged at $13000 \mathrm{rpm}$ for $10 \mathrm{~min}$. Precipitated DNA was re-suspended in $50 \mu \mathrm{l}$ of Milli-Q water and stored at $-20^{\circ} \mathrm{C}(24)$.

\section{Molecular identification of actinomycetes isolates to genus and species level}

The environmental isolates identified phenotypically as actinomycetes were further analyzed for genus and species levels using a panel of molecular tests including a genus-specific PCR based on a 618-bp fragment of the $65-\mathrm{kDa}$ heat shock protein for NTM as recommended by Khan and Yadav [31] and, a 596 bp region of the $16 \mathrm{~S}$ rRNA for streptomyces, rhodococcus and nocardia as recommended by Laurent [32], followed by the amplification and direct analysis of almost complete $16 \mathrm{~S}$ rRNA sequencing for species identification as described by Shojaei et al. [9]. Sequencing was performed by ABI 3100 genetic analyzer in the Bioneer Company (South Korea), and the sequence data received were aligned manually with existing sequences of actinomycetes retrieved from the GenBank database and analyzed using the Blast program in GenBank and the jPhydit program [33].

\section{Nucleotide sequence accession numbers}

The GenBank accession numbers for the 16S rRNA sequencing of isolated actinomycetes in this study are listed below., M. mucogenicum (MT705619), M. conceptionense (MT705620), M. abscessus (MT705885), M. frederiksbergense like (MT708075), M. doricum (MT708129), M. flavescens (MT708131), M. fortuitum (MT708130), M. septicum (MT708132), M. setense (MT708076), M. lentiflavum (MT708077) and M. gordonae (MT705886), $R$. equi (MT734027), $R$. facians 


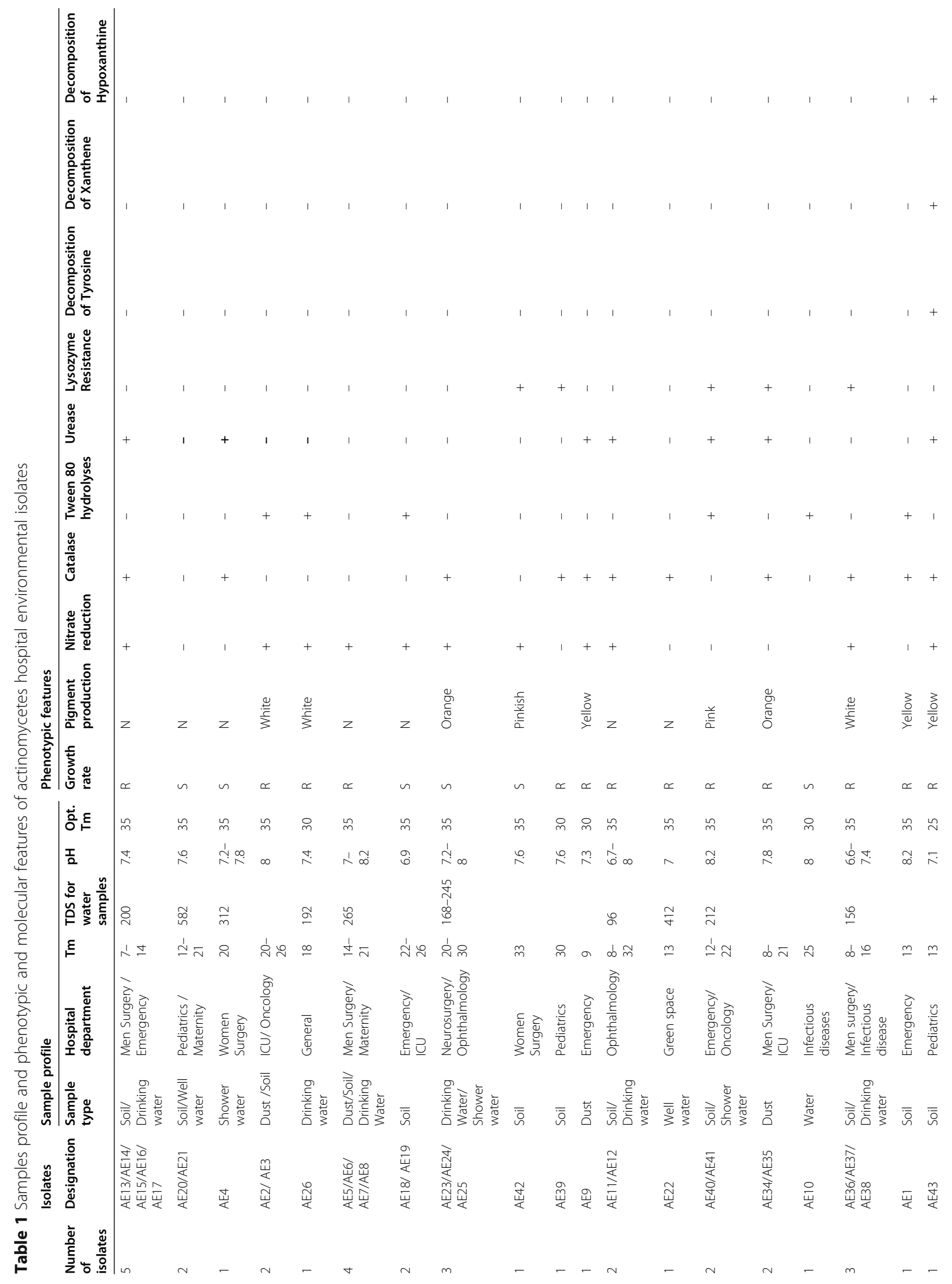




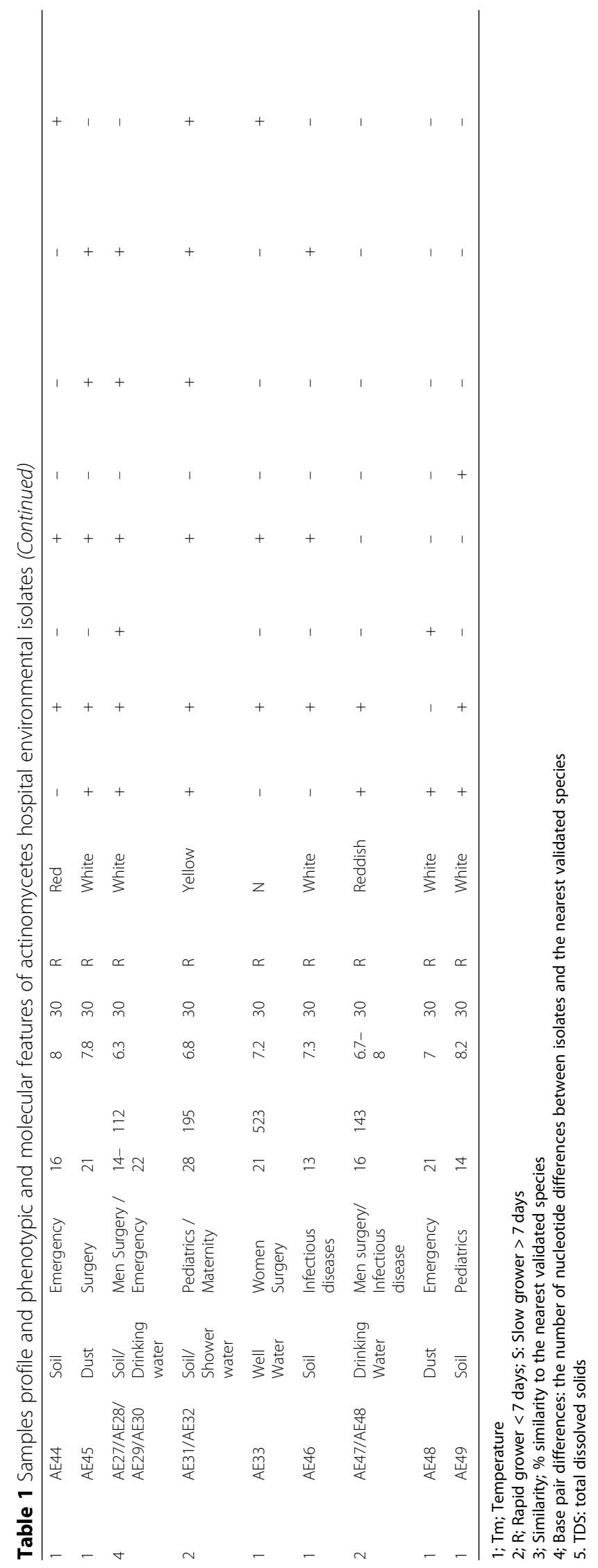




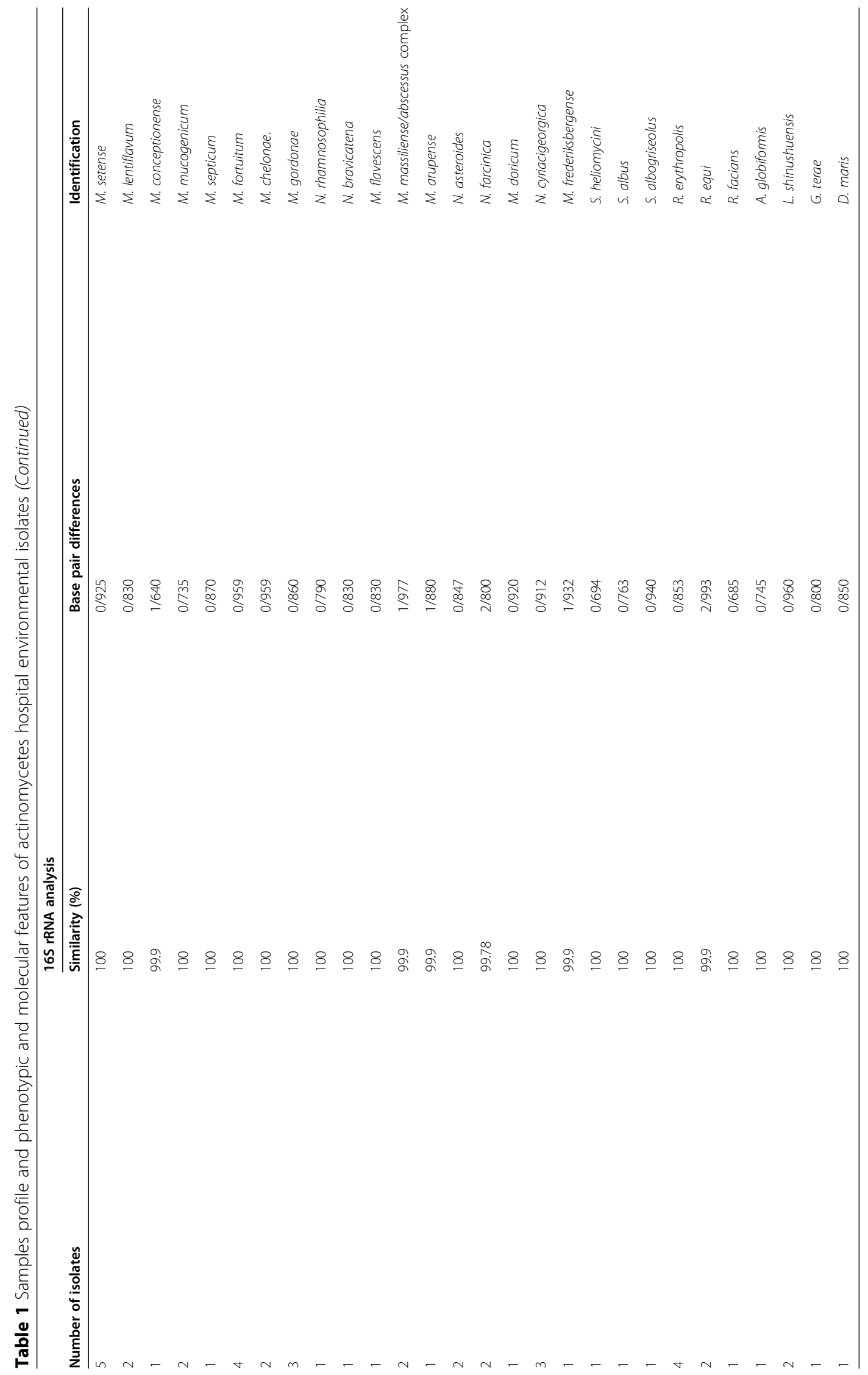


(MT734027), R. erythropolis (MT734047), N. farcinica (MT734045), N. cyriacigeorgica (MT734049), N. bravicatena (MT734050), N. asteroides (MT734070), N. rhamnosophila (MT734071), S. albus (MT734111), S. albogriseolus (MT734112), A. globiformis (MT734564), L. shinushuensis (MT734570), D. maris (MT734648) .

\section{Result}

In this study, a total of 50 (35.2\%) actinomycetes isolates were collected from 142 water, soil and dust samples collected from Markazi province hospitals. Total of 28 (19.7\%) samples were contaminated with gram-positive and gram-negative bacteria and fungi. The positive samples came from the 8 of 13 hospitals; no actinomycetes were detected in any of the analyzed samples taken from the 5 other hospitals (Fig. 1). Of the total isolates, 32 isolates were recovered from dust and soil samples and 18 isolates were recovered from water samples.

The recorded temperature and the $\mathrm{pH}$ of the water samples were between 9 and $33^{\circ} \mathrm{C}$ and $6-8.5$, respectively. The total dissolved solids for the water samples ranged between 284 and $618 \mathrm{mg} / \mathrm{L}$. The corresponding figures for soil samples were in the range of 11 to $28^{\circ} \mathrm{C}$ 6.8 to 8.5. The details of dust, soil and water samples and the isolates are shown in Table 1.
On the basis of morphological, culture, and biochemical features, and the genus specific markers such as, presence of a 618-bp fragment of the hsp65 and a 596 bp fragment of the 16S rRNA, all 50 isolates were identified as actinomycetes (Nocardia, Rhodococcus, Arthrobacter, Streptomyces, Leifsonia, Dietzia, and Mycobacterium), of which 26 isolates were identified as mycobacterium, nine isolates were identified as nocardia, three isolates were identified as streptomyces, two isolates were identified as leifsonia and one isolate was identified as arthrobacter and dietzia, of each.

$16 \mathrm{~S}$ rRNA gene sequences' analysis of the isolates revealed that all isolates had nucleotide signatures of actinomycetes, at positions 70-98 (U-A), 139-224 (G-C), 843(C), 1008-1021 (C-G), 1189 (C), 1244-129 (C-G) and 1308-1329 (C-G) for mycobacterium and at positions 70-98 (A-T), 293-304 (G-T), $307(\mathrm{C}), 328(\mathrm{~T})$, 614-626 (A-T), 631(G), 661-744 (G-C), 824e876 (T-A), 825-875 (A-T), 843 (C), and 1122-1151 (A-T) for nocardia and streptomyces [34].

The most prevalent Iranian actinomycetes species isolated from hospital environmental samples were $M$. setense 5 isolates (10\%), M. fortuitum and R. erythropolis 4 isolates each (8\%), N.cyriacigeorgica and M. gordonae 3 isolates each (6\%), M. chelonae, M. abscessus, $M$.

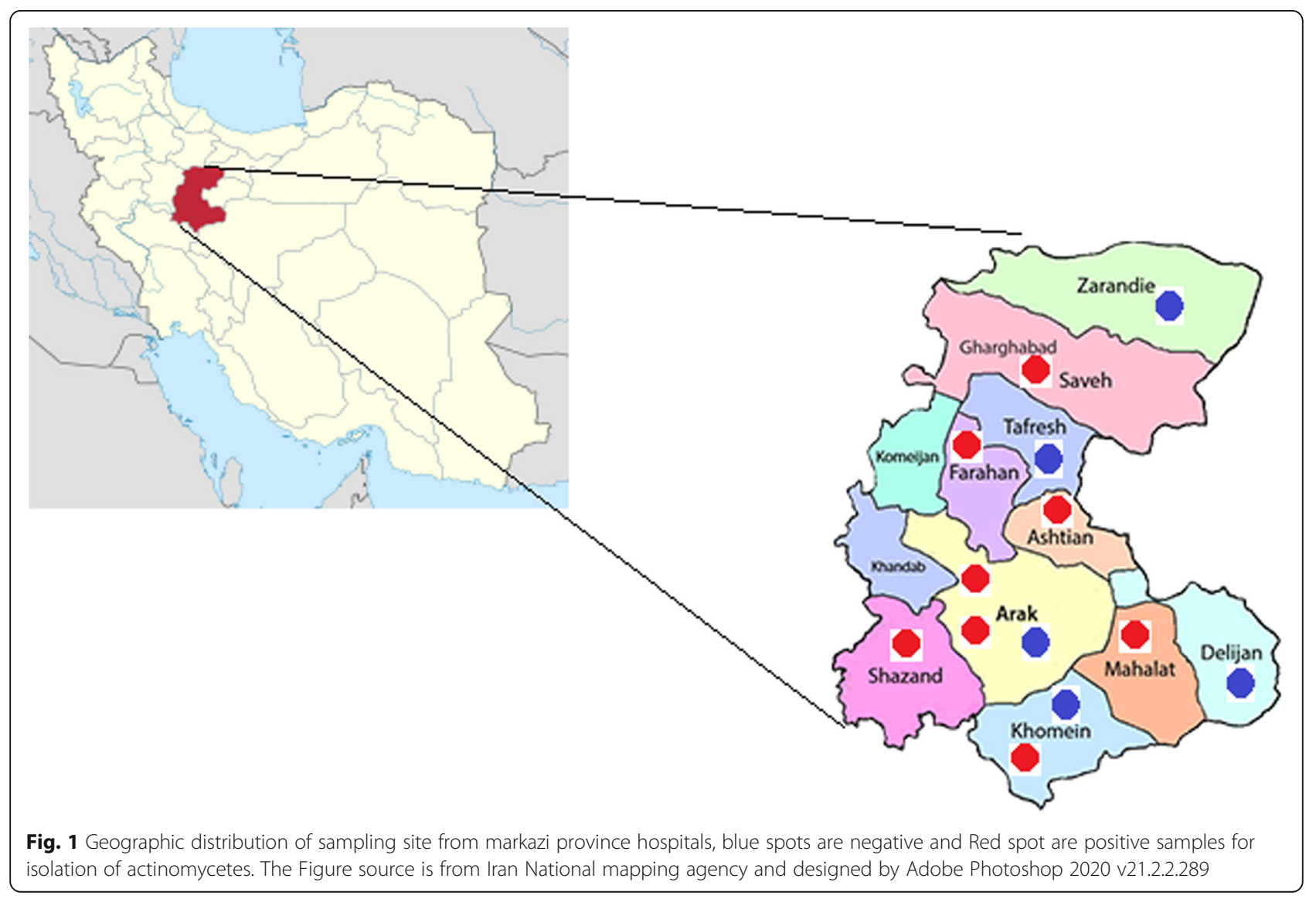


lentiflavum, M. mucogenicum, $N$. asteroides, $N$. farcinica, $R$. equi and $L$. shinushuensis 2 isolates each (4\%) and 15 species including., $M$. conceptionense, $M$. septicum, $N$. rhamnosophilia, N. bravicatena, M. flavescens, M. arupense, M. doricum, M. frederiksbergense, S. heliomycini, $S$. albus, S. albogriseolus, R. facians, D. maris, G. terae and A. globiformis consisted a single isolate. The almost complete 16S rRNA gene sequences obtained from the species' accurate identification of clinical isolates represented that all isolates had $100 \%$ similarity with the nearest standard type strain of actinomycetes species.

The phylogenic relationship between environmental actinomycetes isolates and the validated actinomycetes species was presented by phylogenetic tree of $16 \mathrm{~S}$ rRNA and by the high bootstrap value obtained using the neighbor-joining method with arithmetic mean using the matrix of pairwise differences. (Fig. 2).

\section{Discussion}

Members of actinomycetes group are widely distributed in nature and are found in water, dust, soil, and decaying vegetation [18], and also frequently found as members of the normal microbiota of oropharynx, gastrointestinal tract, upper respiratory tract, and female genital tract of human and animal in [35].

Nowadays infections due to different species of actinomycetes such as nocardia, mycobacterium, rhodococcus, streptomyces, gordonae and actinomyces. Have gained considerable importance because of their increasing incidence in immunocompromised patients as well as in immunocompetent patients [36, 37]. Infections due to actinomycetes group members are clinically hard to differentiate from M. tuberculosis [38, 39]. Some actinomycetes species based on their high lipid content and triple-layered cell wall, they have a remarkable stress tolerance, which leads to more resistant to killing in a harsh environmental condition such as normal disinfection, elevated temperature, and ultraviolet light compared with other pathogenic bacteria that may colonize in hospital environment [40]. Due to this issue the use of colonized aqueous solutions and inadequate sterilization or disinfection of hospital room and environment and equipment are often factors in nosocomial infections by actinomycetes species. Despite of these group's ability to spread by aerosolization and direct contact to human and their slow growth, there is a significant reason to study actinomycetes species in various environments and that is the fact that these species may play the role of emerging pathogens [41, 42].

Water, soil and decaying vegetation are the major sources of these opportunistic bacteria [43]. Nevertheless, environmental resources of hospitals, especially in developing countries are not evaluated for the presence of actinomycetes group species. On the other hand, the majority of bacteriological tests commonly used in laboratories are not able to detect actinomycetes species in water, soil and dust $[44,45]$. This may be the most important but neglected factor influencing the spread of these opportunistic organisms in critical environments, including nursing homes, hospitals, prisons and other similar places [46, 47]. This fact is described by reports of cases such as gastrointestinal tract infections, ocular infections, pulmonary infections and cutaneous or soft tissue infections particularly in post-surgery patients [48-50].

Likewise, contamination of hospital medication and equipment, traced for the persistence of actinomycetes species in hospital environmental resources and their resistance to commonly used disinfectants [51], was responsible for pseudo-outbreaks of infections related to surgical implants, lung disease following bronchoscopy and health care-associated septicemia $[48,50]$.

Increasing isolation of actinomycetes species from environmental and clinical sources in different parts of the world [52-55] prompted us to design the present study to determine the extent of the actinomycetes diversity in hospital environmental samples of Markazi province of Iran. We envisaged that optimization of methods in isolation and accurate identification of actinomycetes group species recovered from water, soil and dust samples by application of conventional microbiologic and molecular approaches is a key step towards the description of the emerging infections that they cause but are often ignored or missed.

In the current study, our isolation rate of actinomycetes species from hospital environmental resources samples was found to be $35.2 \%$. We were unable to compare the isolation rate of actinomycetes species in this study with that of other studies, since a thorough literature review revealed there were no published research studies on isolation of actinomycetes species from water, dust and soil samples in hospitals.

The actinomycetes species recovered from environmental samples in our study were 13 mycobacterial species included M. fortuitum, M. chelonae, M. abscessus, M. lentiflavum, M. mucogenicum, M. setense, M. conceptionense, M. septicum, M. gordonae, M. flavescens, $M$. arupense, $M$. doricum, and $M$. frederiksbergense, and four nocardia species included $N$. rhamnosophilia, $N$. bravicatena, $N$. asteroides, and $N$. farcinica, three rhodococcus and streptomyces species included, $R$. equi. $R$. facians, R. erythropolis, S. albus, S. albogriseolus, and $S$. heliomycini and one species of D. maris, G. terae, A. globiformis and, L. shinushuensis. Based on literature of review, among the actinomycetes species isolated in this study, 16 species and 11 species were shown that are opportunistic pathogens and non- pathogens, respectively. In our study, some similar actinomycetes strains were 


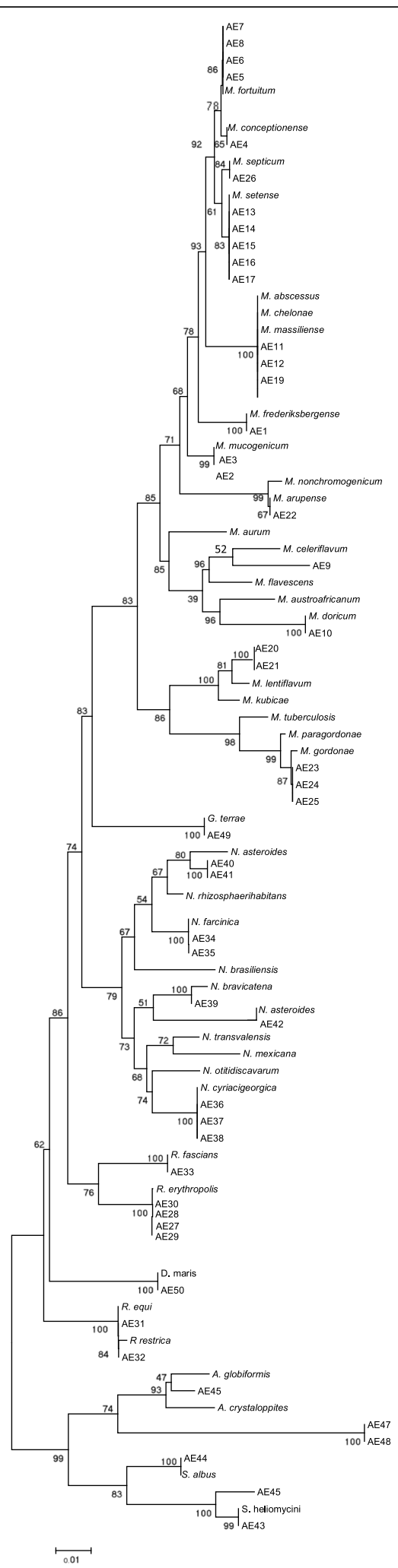

Fig. 2 16S rRNA sequence based phylogenetic tree for environmental actionmycetes and nearest validated species of actinomycetes by using the neighbor-joining method. The figures at each node represent bootstrapping values isolated by sampling from different places of a hospital ward, which indicated that the entire ward was polluted with these strains.

Result of our study showed that $M$. setense, was the most encountered actinomycetes included 5 isolates (10\%), following that M. fortuitum, and $R$. erythropolis included 4 isolates of each (8\%). These findings are in accordance with another report from various parts of the world showing $M$. fortuitum, $R$. erythropolis and $M$. setense are most common actinomycetes species isolated from environmental sample [56-59]. In the current study these species were isolated from soil dust and water samples of hospitals.

$N$. cyriacigeorgica and M. gordonae ranked third included 6\% (3 Isolates) of all the isolates. N. cyriacigeorgica is a human opportunistic pathogen that was first isolated and characterized, in 2001, from the bronchial secretions of a patient with chronic bronchitis [60] and $M$. gordonae is one of the most common mycobacterial species was isolated from hospital water resources [61]. In this study we isolated this species from water and the soil of decayed vegetation pots in patient's room in hospitals.

In our study, eight isolates included M. chelonae, $M$. abscessus, M. lentiflavum, M. mucogenicum, N. asteroides, N. farcinica, R. equi and L. shinushuensis ranked fourth with a frequency of $2(4 \%)$ isolates each among all Iranian actinomycetes isolates. M. lentiflavum is a rare slow-growing human opportunistic pathogen closely related to M. simiae and M. genavense [62, 63]. M. mucogenicum is a rapidly growing mycobacterium found ubiquitously in water resources. It has been reported as a cause of widespread infections entering from wound or central venous catheters especially in immunocompromised patients [64]. In this study these species were isolated from water and soil samples in hospitals.

M. chelonae and M. massiliense/abscessus complex is a rapidly growing mycobacterium that is a common water contaminant [65]. Several reports have indicated that these organisms can be the cause of post-traumatic wound infections, chronic lung disease, ocular infection, disseminated cutaneous diseases and persistent culturenegative skin infections, mostly in patients with suppressed immune system, although $M$. chelonae can cause the pseudo-epidemics in hospitals [66, 67]. In this study these species were isolated from water samples in hospitals.

$N$. asteroides and N. farcinica are the first historically identified nocardia species and have been the most commonly reported isolates from clinical and environmental samples worldwide [4]. R. equi, R. facians and L. shinushuensis generally found in dry and dusty soil and water resources and can be important for diseases of domesticated animals [4]. In this study we recovered these 
species from water, distilled water, dust and soil samples in hospitals.

In the current study we reported isolation of $M$. conceptionense, M. septicum, N. rhamnosophilia, N. bravicatena, $M$. flavescens, $M$. arupense, and $M$. doricum, taken from hospital water and dust samples. These organisms are rare actinomycetes originally isolated from clinical specimens; our study reports the isolation of these organisms from the hospital environmental resources such as water, soil and dust [68-70]. This could be an indicative of the source of these microorganisms in the environment.

M. frederiksbergense S. heliomycini, S. albus, S. ablogriseolus, D. maris, G. terae and A. globiformis were commonly found in soil and sediment, and have the biodegrading ability of pollution, as well as produced antimicrobial agent $[71,72]$. To date, there have been no reports on the clinical significance of these organisms [72].

\section{Conclusion}

In conclusion, the present study showed that hospital environmental resources can be the reservoir of a wide range of opportunistic actinomycetes which can act as a potential supplier for transmission of opportunistic infections to patients. Moreover, our study once more signified the fact that the occurrence of actinomycetes species in hospital environment is worth to be considered, since these organisms show a high degree of intrinsic resistance to common antiseptic and disinfectant solutions and are able to threat patients' health, particularly in those suffering from weakness of immunity. Furthermore, taking the role of a variety of hospital devices in transmission of actinomycetes to vulnerable patients into consideration might be of interest and may help to the better assessment of problem dimensions.

\section{Abbreviations}

AIDS: Acquired immunodeficiency syndrome; HAl: hospital-acquired infection; NTM: Nontuberculous Mycobacteria; PRA: PCR-based RFLP; CPC: cetylpyridinium chloride; LJ: Lowenstein-Jensen; SDS: sodium dodecyl sulfate; TE: Tris EDTA

\section{Acknowledgements}

The authors are grateful to office of vice-chancellor for research of Khomein University of Medical Sciences for financial support of the current study (Grant No. 98000018).

\section{Authors' contributions}

DA, TMR and MSF designed the work and contributed to the writing of the manuscript. DA, ZNR, FR and AA carried out the laboratory work and statistical analysis. KGH and MJ participated in the revision and provided assistance in data analysis and revision. All authors approved the final version.

\section{Funding}

This work was supported by Khomein University of Medical Sciences (Grant No. 98000018)

The funding bodies had no role in the design of the study, in data collection, analysis or interpretation, or in writing the manuscript.

\section{Availability of data and materials}

The data that support the findings of this study are available from the corresponding author upon reasonable request.

\section{Ethics approval and consent to participate}

The Ethics Committee of Khomein University of Medical Sciences approved this study, and this article does not contain any studies with human or animal subjects performed by any of the authors.

\section{Consent for publication}

Not applicable.

\section{Competing interests}

The authors declare that there are no conflicts of interest.

\section{Author details}

${ }^{1}$ Student Research Comitee, Khomein University of Medical Sciences, Khomein, Iran. ${ }^{2}$ Department of Basic and Laboratory and Sciences, Khomein University of Medical Sciences, Qods street, Khomein, Iran. ${ }^{3}$ Department of Immunology, School of Medicine, Isfahan University Of Medical Sciences, Isfahan, Iran.

Received: 16 October 2020 Accepted: 15 January 2021

Published online: 28 January 2021

\section{References}

1. Dilip CV, Mulaje S, Mohalkar R. A review on actinomycetes and their biotechnological application. Int J Pharm Sci Res. 2013;4(5):1730.

2. Oskay AM, Üsame T, Cem A. Antibacterial activity of some actinomycetes isolated from farming soils of Turkey. Afr J Biotechnol. 2004;3(9):441-6.

3. Shrivastava S, D'Souza S, Desai P. Production of indole-3-acetic acid by immobilized actinomycete (Kitasatospora sp.) for soil applications. Curr Sci. 2008:1595-604.

4. Conville PS, Witebsky FG. Nocardia, rhodococcus, gordonia, actinomadura, streptomyces, and other aerobic actinomycetes. Manual of Clinical Microbiology, 10th Edition: American Society of Microbiology; 2011. p. 44371.

5. Shojaei $H$, Heidarieh $P$, Hashemi A, Feizabadi MM, Naser AD. Species identification of neglected nontuberculous mycobacteria in a developing country. Jap J Infect Dis. 2011;64(4):265-71.

6. da Silva P, Santos ACB, Sato DN, Silva JO, Medeiros MIC, Carneiro AMM, et al. Phenotypic and genotypic characterization of Rhodococcus equi isolated from sputum. Braz J Infect Dis. 2012;16(5):409-15.

7. Cortez-Escalante JJ, dos Santos AM, de Curcio Garnica G, Sarmento AL, de Castro CN, GAS R. Mediastinitis and pericardial effusion in a patient with AIDS and disseminated Mycobacterium avium infection: a case report. Rev Soc Bras Med Trop. 2012;45(3):407-9.

8. Wong VK, Turmezei T, Weston V. Actinomycosis. Bmj. 2011;343.

9. Shojaei H, Heidarieh P, Hashemi A, Feizabadi M. Daei Naser a; species identification of neglected nontuberculous mycobacteria in a developing country. Jpn J Infect Dis. 2011;64(4):265-71.

10. Dominguez DC, Antony SJ. Actinomyces and nocardia infections in immunocompromised and nonimmunocompromised patients. J Nation Med Assoc. 1999;91(1):35.

11. Stewart A, Sowden D, Caffery M, Bint M, Broom J. Rhodococcus equi infection: a diverse spectrum of disease. IDCases. 2019;15:e00487.

12. Solano-Varela DM, Barrios-Vidales EM, Plaza DF, Riveros WM, Guzmán J, Chica CE, et al. Immunocompetent patient with a brain abscess caused by Nocardia beijingensis in Latin America: A case report. Medicine. 2019;98(11): e14879.

13. Rolfe R, Steed LL, Salgado C, Kilby JM. Actinomyces meyeri, a common agent of Actinomycosis. Am J Med Sci. 2016;352(1):53-62.

14. Javadi A, Pourmand MR, Hamedi J, Eshraghi SS. Diversity of Nocardia species isolated from transplantation and cancer centers of Tehran hospitals. J Acut Dis. 2020;6:255-9.

15. Li T, Abebe LS, Cronk R, Bartram J. A systematic review of waterborne infections from nontuberculous mycobacteria in health care facility water systems. Int J Hyg Environ Health. 2017;220(3):611-20.

16. Faircloth EL, Troy P. A Rare Presentation of Nocardia pericarditis Leading to Cardiac Tamponade in an Immunocompetent Patient. Cureus. 2019;11(2): e4140. 
17. Gundelly P, Suzuki Y, Ribes JA, Thornton A. Differences in Rhodococcus equi infections based on immune status and antibiotic susceptibility of clinical isolates in a case series of 12 patients and cases in the literature. BioMed Res Int. 2016;2016:2737295.

18. Saubolle MA. Aerobic actinomycetes. Diagnostic Microbiology of the Immunocompromised Host. Amer Soci of Microbiol. 2009:269-81.

19. Falkinham JO. Current epidemiologic trends of the nontuberculous mycobacteria (NTM). Curr Environmen Heal Rep. 2016;3(2):161-7.

20. Falkinham IJ. Surrounded by mycobacteria: nontuberculous mycobacteria in the human environment. J Appl Microbiol. 2009;107(2):356-67.

21. Jeon D. Infection source and epidemiology of nontuberculous mycobacterial lung disease. Tubercul Resp Dis. 2019;82(2):94-101.

22. Azadi D, Motallebirad T, Ghaffari K, Shokri D, Rezaei F. Species diversity, molecular characterization, and antimicrobial susceptibility of opportunistic Actinomycetes isolated from Immunocompromised and healthy patients of Markazi Province of Iran. Infec Drug Resis. 2020;13:1-10.

23. Brown-Elliott BA, Brown JM, Conville PS, Wallace RJ. Clinical and laboratory features of the Nocardia spp. based on current molecular taxonomy. Clin Microbiol Rev. 2006;19(2):259-82.

24. Rajivgandhi G, Ramachandran G, Maruthupandy M, Vaseeharan B, Manoharan N. Molecular identification and structural characterization of marine endophytic actinomycetes Nocardiopsis sp. GRG 2 (KT 235641) and its antibacterial efficacy against isolated ESBL producing bacteria. Microb Pathog. 2019;126:138-48.

25. Thomson R, Carter R, Gilpin C, Coulter C, Hargreaves M. Comparison of methods for processing drinking water samples for the isolation of Mycobacterium avium and Mycobacterium intracellulare. Appl Environ Microbiol. 2008;74(10):3094-8.

26. Kamala T, Paramasivan C, Herbert D, Venkatesan P, Prabhakar R. Evaluation of procedures for isolation of nontuberculous mycobacteria from soil and water. Appl Environ Microbiol. 1994;60(3):1021-4.

27. Baskaran R, Vijayakumar R, Mohan P. Enrichment method for the isolation of bioactive actinomycetes from mangrove sediments of Andaman Islands. India Malaysian J Microbiol. 2011;7(1):1-7.

28. El Amin NM, Hanson H-S, Pettersson B, Petrini B, Von Stedingk LV. Identification of non-tuberculous mycobacteria: 16S rRNA gene sequence analysis vs. conventional methods. Scand J Infect Dis. 2000;32(1):47-50.

29. Pitcher D, Saunders N, Owen R. Rapid extraction of bacterial genomic DNA with guanidium thiocyanate. Lett Appl Microbiol. 1989;8(4):151-6.

30. Bafghi MF, Eshraghi SS, Heidarieh P, Habibnia S, Nasab MR. DNA extraction from nocardia species for special genes analysis using PCR. North Am J Med Sci. 2014;6(5):231.

31. Khan IU, Yadav JS. Development of a single-tube, cell lysis-based, genusspecific PCR method for rapid identification of mycobacteria: optimization of cell lysis, PCR primers and conditions, and restriction pattern analysis. J Clin Microbiol. 2004:42(1):453-7.

32. Laurent FJ, Provost F, Boiron P. Rapid identification of clinically relevant Nocardia species to genus level by 165 rRNA gene PCR. J Clin Microbiol. 2000:38(7):2805.

33. Jeon Y-S, Chung H, Park S, Hur I, Lee J-H, Chun J. jPHYDIT: a JAVA-based integrated environment for molecular phylogeny of ribosomal RNA sequences. Bioinformatics. 2005;21(14):3171-3.

34. Stackebrandt E, Rainey FA, Ward-Rainey NL. Proposal for a new hierarchic classification system, Actinobacteria classis nov. Int J Syst Evol Microbiol. 1997;47(2):479-91.

35. Pierre I, Zarrouk V, Noussair L, Molina J-M, Fantin B. Invasive actinomycosis: surrogate marker of a poor prognosis in immunocompromised patients. Int J Infect Dis. 2014;29:74-9.

36. Moore JEKM, Ormerod LP, Drobniewski F, Abubakar I. Increasing reports of non-tuberculous mycobacteria in England, Wales and Northern Ireland. BMC Public Health. 2010;10(1):612.

37. Drage LA, Ecker PM, Orenstein R, Phillips PK, Edson RS. An outbreak of Mycobacterium chelonae infections in tattoos. J Am Acad Dermatol. 2010; 62(3):501-6

38. Lopez-Varela E, Garcia-Basteiro AL, Santiago B, Wagner D, van Ingen J, Kampmann B. Non-tuberculous mycobacteria in children: muddying the waters of tuberculosis diagnosis. Lancet Respir Med. 2015;3(3):244-56.

39. Wallace RJ Jr, Glassroth J, Griffith DE, Olivier KN, Cook JL, Gordin F. Diagnosis and treatment of disease caused by nontuberculous mycobacteria. This official statement of the American Thoracic Society was approved by the
Board of Directors, March 1997. Medical Section of the American Lung Association. Am J Respir Crit Care Med. 1997;156(2 Pt 2):S1-25.

40. Vaerewijck MJ, Huys G, Palomino JC, Swings J, Portaels F. Mycobacteria in drinking water distribution systems: ecology and significance for human health. FEMS Microbiol Rev. 2005;29(5):911-34.

41. Primm TP, Lucero CA, Falkinham JO 3rd. Health impacts of environmental mycobacteria. Clin Microbiol Rev. 2004;17(1):98-106.

42. Falkinham JO 3rd. Ecology of nontuberculous mycobacteria--where do human infections come from? Semin Respir Crit Care Med. 2013;34:95-102.

43. Falkinham JO 3rd. Environmental sources of nontuberculous mycobacteria. Clin Chest Med. 2015;36(1):35-41.

44. Khan SSM, Jehan N, Rehman S, Shah MT, Din I. Drinking water quality and human health risk in Charsadda district, Pakistan. J Clean Prod. 2013;60:93101.

45. Whiley H, Keegan A, Giglio S, Bentham R. Mycobacterium avium complex-the role of potable water in disease transmission. J Appl Microbiol. 2012; 113(2):223-32.

46. Lai CC, Tan CK, Chou CH, Hsu HL, Liao CH, Huang YT, et al. Increasing incidence of nontuberculous mycobacteria, Taiwan, 2000-2008. Emerg Infect Dis. 2010;16(2):294-6.

47. Carbonne A, Brossier F, Arnaud I, Bougmiza I, Caumes E, Meningaud JP, et al. Outbreak of nontuberculous mycobacterial subcutaneous infections related to multiple mesotherapy injections. J Clin Microbiol. 2009:47(6): 1961-4.

48. Wallace RJBB, Griffith DE. Nosocomial outbreaks/pseudo-outbreaks caused by nontuberculous mycobacteria. Annu Rev Microbiol. 1998;52:453-90.

49. Ortiz AEJ, Zamora N. Molecular identification by random amplified polymorphic DNA analysis of a pseudo-outbreak of Mycobacterium fortuitum due to cross-contamination of clinical samples. J Med Microbiol. 2007;56(6): 871-2.

50. Fernandes Garcia de Carvalho N, Rodrigues Mestrinari AC, Brandao A, Souza Jorge L, Franco C, da Silveira Paro Pedro H, et al. Hospital bronchoscopyrelated pseudo-outbreak caused by a circulating Mycobacterium abscessus subsp. massiliense. J Hosp Infect. 2018;100(3):e138-e41.

51. Farias PGGF, Reis D, Alarico S, Empadinhas N, Martins JC, de Almeida AF, Morais PV. Hospital microbial surface colonization revealed during monitoring of Klebsiella spp., Pseudomonas aeruginosa, and non-tuberculous mycobacteria. Antonie Van Leeuwenhoek. 2017;110(7):863-76.

52. Boyanova L, Kolarov R, Mateva L, Markovska R, Mitov I. Actinomycosis: a frequently forgotten disease. Future Microbiol. 2015;10(4):613-28.

53. DeWitt JP, Stetson CL, Thomas KL, Carroll BJ. Extensive cutaneous botryomycosis with subsequent development of Nocardia-positive wound cultures. J Cut Med Surg. 2018;22(3):344-6.

54. Kim S, Lee $\mathrm{KL}$, Lee DM, Jeong JH, Moon SM, Seo Y-H, et al. Nocardia brain abscess in an immunocompetent patient. Infect Chemoth. 2014;46(1):45-9.

55. Raby E, Hiew V, Arthur I. A case of Nocardia mexicana cerebral abscess highlights deficiencies in susceptibility testing and the utility of direct molecular identification. Pathology. 2016;48(5):508-10.

56. Prevots DR, Marras TK. Epidemiology of human pulmonary infection with nontuberculous mycobacteria: a review. Clin Chest Med. 2015;36(1):13-34.

57. Tsukamura M, Mizuno S, Murata $H$, Nemoto H, Yugi $H$. A comparative study of mycobacteria from patients' room dusts and from sputa of tuberculous patients. Source of pathogenic mycobacteria occurring in the sputa of tuberculous patients as casual isolates. Jpn J Microbiol. 1974;18(4):271-7.

58. Kettleson E, Kumar S, Reponen T, Vesper S, Méheust D, Grinshpun SA, et al. Stenotrophomonas, Mycobacterium, and Streptomyces in home dust and air: associations with moldiness and other home/family characteristics. Indoor Air. 2013:23(5):387-96.

59. De Groote MA, Pace NR, Fulton K, Falkinham JO. Relationships between Mycobacterium isolates from patients with pulmonary mycobacterial infection and potting soils. Appl Environ Microbiol. 2006;72(12):7602-6.

60. Yassin A, Rainey F, Steiner U. Nocardia cyriacigeorgici sp. nov. Int J Syst Evol Microbiol. 2001;51(4):1419-23.

61. Waak MB, LaPara TM, Hallé C, Hozalski RM. Nontuberculous mycobacteria in two drinking water distribution systems and the role of residual disinfection. Environ Sci Technol. 2019;53(15):8563-73.

62. Shojaei H, Hashemi A, Heidarieh P, Feizabadi MM, Ataei B, Daei NA. First report on isolation and molecular characterization of clinical Mycobacterium setense isolates in Asia. Jpn J Infect Dis. 2011;64(3):234-6. 
63. Tsitko I, Rahkila R, Priha O, Ali-Vehmas T, Terefework Z, Soini H, et al. Isolation and automated ribotyping of Mycobacterium lentiflavum from drinking water distribution system and clinical specimens. FEMS Microbiol Lett. 2006;256(2):236-43.

64. Pradier M, Boucher A, Robineau O, Chachaty E, Meybeck A, Senneville E. Mycobacterium mucogenicum bacteremia: major role of clinical microbiologists. BMC Infect Dis. 2018;18(1):1-3.

65. Lopeman RC, Harrison J, Desai M, Cox JA. Mycobacterium abscessus: environmental bacterium turned clinical nightmare. Microorganisms. 2019; 7(3):90.

66. Brown-Elliott BA, Wallace RJ. Healthcare-associated outbreaks and pseudooutbreaks of Nontuberculous mycobacteria. Nontuberculous Mycobacterial Disease: Springer; 2019. p. 483-503.

67. Roux AL, Catherinot E, Soismier N, Heym B, Bellis G, Lemonnier L, Chiron R, Fauroux B, Le Bourgeois M, Munck A, Pin I. Comparing Mycobacterium massiliense and Mycobacterium abscessus lung infections in cystic fibrosis patients. J Cyst Fibros. 2015;14(1):63-9.

68. Turenne C, Chedore P, Wolfe J, Jamieson F, May K, Kabani A. Phenotypic and molecular characterization of clinical isolates of Mycobacterium elephantis from human specimens. J Clin Microbiol. 2002;40(4):1230-6.

69. Dean-Ross D, Cerniglia CE. Degradation of pyrene by Mycobacterium flavescens. Appl Microbiol Biotechnol. 1996:46(3):307-12.

70. Schinsky MF, MCNeil MM, Whitney AM, Steigerwalt AG, Lasker BA, Floyd MM, et al. Mycobacterium septicum sp. nov., a new rapidly growing species associated with catheter-related bacteraemia. Int I Syst Evol Microbiol. 2000; 2:575-81.

71. Wang D, Wang C, Gui P, Liu H, Khalaf SM, Elsayed EA, et al. Identification, bioactivity, and productivity of actinomycins from the marine-derived Streptomyces heliomycini. Front Microbiol. 2017;8:1147.

72. Willumsen P, Karlson U, Stackebrandt E, Kroppenstedt RM. Mycobacterium frederiksbergense sp. nov., a novel polycyclic aromatic hydrocarbondegrading Mycobacterium species. Int J Syst Evol Microbiol. 2001;51(Pt 5): 1715-22.

\section{Publisher's Note}

Springer Nature remains neutral with regard to jurisdictional claims in published maps and institutional affiliations.

Ready to submit your research? Choose BMC and benefit from:

- fast, convenient online submission

- thorough peer review by experienced researchers in your field

- rapid publication on acceptance

- support for research data, including large and complex data types

- gold Open Access which fosters wider collaboration and increased citations

- maximum visibility for your research: over $100 \mathrm{M}$ website views per year

At $\mathrm{BMC}$, research is always in progress.

Learn more biomedcentral.com/submissions 